\title{
Chromium yeast affects growth performance but not whole carcass composition of growing-finishing pigs
}

\author{
Andreas Lemme ${ }^{\mathrm{a} *}$, Caspar Wenk ${ }^{\mathrm{a}}$, Merlin Lindemann ${ }^{\mathrm{b}}$, \\ Giuseppe Bee
}

\author{
${ }^{a}$ Institute of Animal Science, Nutrition Biology Group, Federal Institute of Technology, \\ Zurich, Switzerland \\ ${ }^{b}$ Department of Animal Science, University of Kentucky, Lexington, Kentucky, USA \\ ${ }^{c}$ Swiss Federal Research Station for Animal Production, Posieux, Switzerland
}

(Received 19 February 1999; accepted 3 August 1999)

\begin{abstract}
An experiment with 40 pigs ( $24.5 \mathrm{~kg}$ initial and $105.5 \mathrm{~kg}$ final live weight) was conducted to investigate the effects of supplemented trivalent chromium $(\mathrm{Cr})$ from chromium yeast on growth performance, carcass composition, fatty acid profile of the carcass fat, and blood parameters both after a 24-h fasting period and $2 \mathrm{~h}$ after feeding. Ten pigs per treatment were fed a barley-wheat-soybean meal diet supplemented with either 0 (C), $200(\mathrm{C} 200), 400(\mathrm{C} 400)$ or $800 \mathrm{ppb} \mathrm{Cr}(\mathrm{C} 800)$ at a restricted feeding scale. Pigs receiving the $\mathrm{C} 200$ treatment showed both improved average daily gains and feed conversion ratios compared to those receiving treatment $\mathrm{C}$ for the total experiment $(P<0.06)$, especially in the finishing period. While carcass measurements and composition, as well as the fatty acid profile, were not significantly affected by the $\mathrm{Cr}$ supply, concentrations of plasma insulin, triglycerides, non-esterified fatty acid (NEFA), urea $\mathrm{N}$ and ketone bodies gave evidence that supplemented $\mathrm{Cr}$ affected carbohydrate and fat metabolisms. The failure of plasma metabolite changes to be reflected in the whole body composition may have been dependent on the genotype (lean in this experiment) and the manner of feeding (restricted feeding scale in this experiment vs. ad libitum in other reported experiments). (@ Elsevier / Inra)
\end{abstract}

\section{chromium / pig / carcass / hormones}

Résumé - La levure enrichie en chrome affecte les performances de croissance mais pas la composition des carcasses de porcs en fin d'engraissement. Un essai avec 40 porcs (d'un poids vif moyen et final de 24,5 et $105,5 \mathrm{~kg}$ respectivement) a été conduit pour étudier les effets d'une supplémentation en chrome trivalent $(\mathrm{Cr})$ sous forme de levure de chrome sur les performances de croissance, la composition de la carcasse, le profil des acides gras des lipides de la carcasse et les paramètres sanguins après une période de jeûne de $24 \mathrm{~h}$ et $2 \mathrm{~h}$ après le repas. Les animaux (dix par traitement)

* Correspondence and reprints

Tel.: (41) 163232 70; fax: (41) 163211 28; andreas.lemme@inw.agrl.ethz.ch 
ont reçu une alimentation rationnée à base d'orge, de blé et de soja, additionnée soit de $0(\mathrm{C})$, 200 (C200), 400 (C400) ou 800 ppb (C800) de chrome. Les porcs du traitement C200 ont présenté un gain de poids quotidien moyen et un indice de consommation meilleurs que ceux du traitement $\mathrm{C}$ sur la totalité de la période expérimentale $(p<0,06)$ et plus particulièrement en fin de période d'engraissement. La supplémentation en chrome n'a influencé significativement ni la composition et les mesures de carcasse ni le profil des acides gras ; au contraire des concentrations plasmatique d'insuline, de triglycérides de NEFA, d'azote uréique, et de corps cétoniques qui ont clairement démontré son effet sur le métabolisme glucidique et lipidique. La lignée génétique utilisée dans cet essai (animaux de type maigre) et le mode d'alimentation (restrictif et non ad libitum comme dans d'autres essais) sont peut-être la cause du non-recouvrement des changements observés dans les métabolites plasmatiques et dans la composition de la carcasse. (@ Elsevier/Inra)

chrome / porc / carcasse / hormones

\section{INTRODUCTION}

Trivalent chromium $(\mathrm{Cr})$ is thought to interact with functions of the thyroid hormones, to affect nucleic acid metabolism and to be involved in carbohydrate metabolism by altering insulin action [17]. Since these metabolic pathways influence growth, it is not surprising that dietary $\mathrm{Cr}$ supplementation has been found to affect feed intake, daily gain and feed efficiency in growing-finishing pigs $[3,14,25]$. Special interest has been focused on $\mathrm{Cr}$ research in pig nutrition since dietary $\mathrm{Cr}$ was reported to increase lean body mass and decrease the percentage of body fat content $[20,21,25]$.

The content of total $\mathrm{Cr}$ in food is low and often below $100 \mathrm{ppb}$ [13], especially with respect to cereals [22]. Moreover, only a small proportion of total $\mathrm{Cr}$ is bioavailable and hence can be utilised by humans or animals, implying that $\mathrm{Cr}$ supplementation is necessary [22]. However, several known (and probably also unknown) individual and environmental factors interact with dietary $\mathrm{Cr}$, resulting in apparently inconsistent responses of various parameters due to $\mathrm{Cr}[3$, $14,19,25,30]$.

Therefore, an experiment with growingfinishing pigs was performed under Swiss conditions (i.e. use of lean pig breed and feeding diets based on wheat-barley-soybean meal at restricted feeding levels, which are in contrast to most published data) to examine the response of increasing levels of $\mathrm{Cr}$ supplemented as $\mathrm{Cr}$ yeast on performance. Special interest was directed to carcass composition and fatty acid profile of the carcass lipids. Analysis of plasma metabolites and hormones were also performed to elucidate the effects of $\mathrm{Cr}$ on carbohydrate, fat and protein metabolism.

\section{MATERIAL AND METHODS}

\subsection{Animals and diets}

Forty castrated male Swiss Large White pigs with average live weights (LW) of $24.5 \mathrm{~kg}$ (initial) and $105.5 \mathrm{~kg}$ (final) were randomly allocated to experimental blocks based on LW into four dietary treatments at two dates (interval of 7 weeks/20 pigs per date/a total of ten pigs per treatment). The barrows were housed in individual pens with concrete floors (with litter) in environmentally controlled buildings under normal husbandry conditions. One pig of the first allocation block was replaced because of illness (diarrhoea).

The basal diet for the growing (25-57 kg LW) and finishing periods (57-105 kg LW) consisted of barley, wheat, wheat starch, middling, soybean meal, sunflower meal and bone fat (table I). The level of nutrients was calculated to meet the requirement for $20-60 \mathrm{~kg}$ growing and $60-100 \mathrm{~kg}$ finishing pigs [4]. The basal growing and finishing diets were split into four treatments with either 0 (C), 200 (C200), 400 (C400), or $800 \mathrm{ppb}$ 
Table I. Ingredient composition of the experimental diets $\left(\mathrm{g} \cdot \mathrm{kg}^{-1}\right)$.

\begin{tabular}{lrr}
\hline Ingredients & Grower & Finisher \\
\hline Barley & 359.5 & 455.0 \\
Wheat & 290.0 & 290.0 \\
Soybean meal 44 \% & 145.5 & 55.0 \\
Wheat starch & 50.0 & 50.0 \\
Middling & 50.0 & 50.0 \\
Sunflower meal & 50.0 & 50.0 \\
Bone fat & 20.0 & 20.0 \\
Calcium carbonate & 15.5 & 13.5 \\
Monocalcium phosphate & 5.0 & 2.0 \\
Lysine-HCl & 4.0 & 4.0 \\
DL-methionine & 0.6 & 0.3 \\
L-threonine 98 \% & 0.9 & 0.8 \\
Salt & 4.2 & 4.2 \\
Premix & 5.0 & 5.0 \\
\hline
\end{tabular}

a Supplied per kilogram of diet: 10000 IU of vitamin A, $1000 \mathrm{IU}$ of vitamin $\mathrm{D}_{3}, 40 \mathrm{IU}$ of vitamin $\mathrm{E}, 4 \mathrm{mg}$ of vitamin $B_{2}, 4 \mathrm{mg}$ of vitamin $\mathrm{B}_{6}, 0.015 \mathrm{mg}$ of vitamin $B_{12}, 1 \mathrm{mg}$ of vitamin $K_{3}, 15 \mathrm{mg}$ of pantothenic acid, $20 \mathrm{mg}$ of niacin, $0.2 \mathrm{mg}$ of folic acid, $60 \mathrm{mg}$ Fe as $\mathrm{FeSO}_{4}, 1 \mathrm{mg} \mathrm{I}$ as $\mathrm{Ca}\left(\mathrm{IO}_{3}\right)_{2}, 0.3 \mathrm{mg} \mathrm{Se}$ as $\mathrm{Na}_{2} \mathrm{Se}, 15 \mathrm{mg}$ $\mathrm{Cu}$ as $\mathrm{CuSO}_{4}, 100 \mathrm{mg} \mathrm{Zn}$ as $\mathrm{ZnO}_{2}, 40 \mathrm{mg} \mathrm{Mn}$ as $\mathrm{MnO}_{2}$.

(C800) of supplemented chromium. Cr was provided as a chromium yeast extract $(20000 \mathrm{ppm} \mathrm{Cr}$, Alltech Biotechnology Center, Nicholasville, Kentucky, USA). The diets were offered as pellets. The animals were fed once a day according to a weight-based feeding scale, whereas water was available ad libitum. The daily feed rations were adapted weekly after weighing the animals.

\subsection{Blood samples}

Two blood samples were collected from each pig on experimental day $88(87.4 \mathrm{~kg} \mathrm{LW})$. After a fasting period of $24 \mathrm{~h}$, blood samples were obtained by vena puncture from the vena cava. Thereafter, the pigs were allowed to consume their daily ration and were bled again exactly $2 \mathrm{~h}$ after the initiation of the feeding. The blood samples were kept on ice until centrifugation at $1500 \mathrm{~g}$ for $15 \mathrm{~min}$ at $4^{\circ} \mathrm{C}$. The collected plasma was frozen immediately and stored $\left(-25^{\circ} \mathrm{C}\right)$ until analysis.

\subsection{Carcass data}

When pigs exceeded a weight of $97 \mathrm{~kg}$ they were slaughtered in the following week. After a fasting period of $24 \mathrm{~h}$, the pigs were slaughtered by electric stunning followed by exsanguination at the abattoir of the 'Swiss Pig Performance Testing Station (MLP) Sempach, Switzerland'. Slaughter and dissection procedures were carried out according to MLP methods [26].

The saw method according to Bee [2] was applied to evaluate the chemical carcass composition. After chilling at $0{ }^{\circ} \mathrm{C}$ for $24 \mathrm{~h}$, the right halves of the carcasses without their heads were frozen at $-30^{\circ} \mathrm{C}$. Each frozen carcass side was sawn to approximately 40 slices by means of an electrical saw and 2.1 to $2.8 \mathrm{~kg}$ of sawdust was collected from each carcass side. Prior to analyses, samples of the sawdust were freeze-dried and minced under liquid nitrogen. It was assumed that the right side of the carcass had the same composition as the left side.

\subsection{Chemical analysis}

Dry matter (DM), ash, crude fibre (CF), crude protein $(\mathrm{CP}=\mathrm{N} \times 6.25)$ and $\mathrm{fat}(\mathrm{SF})$ analysis by the soxhlet extraction method of feed were carried out according to the methods of the VDLUFA [23]. The content of Kjeldahl-nitrogen was analysed using an automated Büchi 323 distillation unit (Büchi Laboratory-Techniques Ltd., Flawil, Switzerland), 665 Dosimat, and 678 Processor (Metrohm Ltd., Herisau, Switzerland). SF was analysed as a petroleum ether extract and gross energy was determined using an anisothermic bomb calorimeter (System C $700 \mathrm{~T}$, IKA Analysentechnik GmbH, Heitersheim, Germany). The diets were analysed for $\mathrm{Cr}$ by graphite furnace atomic absorption spectrometry (AS $\mathrm{PE} / 5100 \mathrm{PC} / \mathrm{ZL}$ ) at the laboratory of the Swiss Federal Research Station for Animal Production (Posieux, Switzerland).

Analyses of the carcass sawdust (DM, ash, $\mathrm{CP}, \mathrm{SF}$ ) were carried out as with feed analyses. Total DM was computed by both moisture loss during freeze-drying and drying at $104^{\circ} \mathrm{C}$. SF was determined without prior $\mathrm{HCl}$-hydrolysis.

Fatty acid profiles of the carcass lipids were determined by gas chromatography of the methyl esters (FAME). The lipids were extracted by a modified method of Hara and Radin [11]: prior to cold extraction with hexane:isopropanol (3:2), 
triundecanine (C 11:0) was added as an internal standard. Subsequently, the extract was filtered through folded paper filters (Schleicher \& Schuell $5951 / 2$ Faltenfilter, $\varnothing 150 \mathrm{~mm}$ ). The FAMEs were prepared by transesterification by sodium hydroxide and boron trifluoride both in methanol according to the method of Metcalfe and Smith [18]. FAMEs were determined using a gas chromatograph (HP 5860 A GC) equipped with a flame ionisation detector. The FAMEs were separated on a $30 \mathrm{~m} * 0.32 \mathrm{~mm}$ Supelcowax TM 10 fused-silica capillary column (Supelco Inc., PA, USA). The oven temperature was as follows: the initial temperature was $160^{\circ} \mathrm{C}$ for $1 \mathrm{~min}$, raised to $190{ }^{\circ} \mathrm{C}$ at a rate of $20^{\circ} \mathrm{C} / \mathrm{min}$; raised to $230^{\circ} \mathrm{C}$ at a rate of $4^{\circ} \mathrm{C} / \mathrm{min}$; held at $230^{\circ} \mathrm{C}$ for $16 \mathrm{~min}$; raised to $250{ }^{\circ} \mathrm{C}$ at a rate of $20^{\circ} \mathrm{C} / \mathrm{min}$; held at $250^{\circ} \mathrm{C}$ for $8 \mathrm{~min}$. The detection temperature was $270^{\circ} \mathrm{C}$ and split at $250^{\circ} \mathrm{C}$. FAMEs were quantified using $\mathrm{C} 11: 0$ as the internal standard and calculated as triglycerides.

Insulin (Pharmacia Insulin RIA 100 Pharmacia $A B$, Uppsala, Sweden) and glucagon (Double Antibody DPC, Los Angeles, CA, USA) as well as $\mathrm{T}_{3}$ and $\mathrm{T}_{4}$ (Coat-A-Count DPC, Los Angeles, CA, USA) were measured using standard RIA methods, whereas glucose, total protein, urea $\mathrm{N}$, cholesterol, high density lipoprotein (HDL) cholesterol, triglycerides (Roche Basel, Switzerland), non-esterified fatty acid (NEFA) (Wako, Germany), and $\beta$-hydroxy-butyrate (BHB) (Sigma Diagnostics, USA) were analysed by means of a Cobas Mira Analyser (Hoffmann-La Roche Ltd., Basel, Switzerland) using standard enzymatic methods.

\subsection{Statistical analysis}

Data were submitted to an analysis of variance (GLM procedures of SAS [27]). Linear and quadratic contrasts were used to evaluate dosedependent effects of chromium. The dietary levels of $\mathrm{Cr}$ were not equally spaced; therefore, the coefficients used to calculate the sums of squares for the polynomial contrasts were calculated by the PROC IML method [27]. The basal diet was included as the $0 \mathrm{ppb}$ level of added Cr. In addition, non-orthogonal single degree of freedom comparisons between C and C200 as well as C and $\mathrm{C} 400$ were performed. The model included terms for the allocation date and blocked initial LW. Individual pig values served as the experimental unit for all response parameters. Results of the chemical composition of the carcasses were adjusted for hot carcass weight by covari- ance. Values of the fatty acid profile were analysed using lipid contents of the DM of the carcasses as covariates. In tables III to VII, leastsquare means and the standard error of the mean, calculated as root MSE $/ \mathrm{Nn}$, are shown. $P$-values greater than 0.10 were considered not significant.

\section{RESULTS}

\subsection{Diet}

The basal diets were formulated to meet nutrient requirements for growing and finishing pigs according to Boltshauser et al. [4]. The results of the analysis verified that all requirements were met, although the values of the CP:digestible energy (DE) ratio were slightly higher than the requirements (table II). The analysed $\mathrm{Cr}$ contents clearly demonstrated an increasing chromium level from the $\mathrm{C}$ diet to the $800 \mathrm{ppb}$ treatment. The total $\mathrm{Cr}$ concentrations of the grower and finisher $\mathrm{C}$ diets were 415 and $376 \mathrm{ppb}$, respectively. The $\mathrm{Cr}$ concentrations in all of the diets containing added $\mathrm{Cr}$ were close to the calculated levels.

\subsection{Growth performance}

In the finishing period, there was a quadratic effect of Cr observed for the average daily weight gain $(P<0.10)$ where pigs fed the $C 200$ diet showed the highest daily gain (table III). For the overall experimental period, the daily gain of the C200 pigs was $5.9 \%$ higher compared to the pigs of treatment $\mathrm{C}(P<0.06)$, whereas daily gain of the pigs fed higher amounts of $\mathrm{Cr}$ was similar to treatment $C$. There was a quadratic response in daily feed intake $(P<0.10)$ in the growing period. In the finishing period, the feed conversion ratio (FCR) was $7.4 \%$ $(P<0.06)$ and in the overall experimental period it was $6.1 \%(P<0.05)$ lower due to supplementation of $200 \mathrm{ppb} \mathrm{Cr}$ compared to treatment $\mathrm{C}$. The FCR was, however, impaired with further incremental $\mathrm{Cr}$ supplementation. 
Table II. Analysed nutrients ( $\mathrm{g} \cdot \mathrm{kg}^{-1}$ dry matter $\left.[\mathrm{DM}]\right)$, energy $\left([\mathrm{MJ}] \cdot \mathrm{kg}^{-1} \mathrm{DM}\right)$ and chromium contents (ppb in DM) of the experimental diets.

\begin{tabular}{|c|c|c|c|c|c|c|c|c|}
\hline & \multicolumn{4}{|c|}{ Grower } & \multicolumn{4}{|c|}{ Finisher } \\
\hline & $\mathrm{C}$ & $\mathrm{C} 200$ & $\mathrm{C} 400$ & $\mathrm{C} 800$ & $\mathrm{C}$ & $\mathrm{C} 200$ & $\mathrm{C} 400$ & $\mathrm{C} 800$ \\
\hline Dry matter & 876 & 876 & 877 & 877 & 875 & 874 & 875 & 875 \\
\hline Ash & 65 & 66 & 64 & 63 & 57 & 56 & 56 & 55 \\
\hline Crude protein & 191 & 198 & 195 & 196 & 163 & 163 & 162 & 161 \\
\hline Crude fat & 36 & 36 & 37 & 37 & 38 & 37 & 38 & 38 \\
\hline Crude fibre & 65 & 58 & 59 & 60 & 59 & 58 & 61 & 63 \\
\hline Nitrogen-free extracts & 644 & 643 & 644 & 644 & 684 & 687 & 683 & 684 \\
\hline Gross energy & 18.55 & 18.54 & 18.37 & 18.55 & 18.42 & 18.48 & 18.51 & 18.58 \\
\hline Digestible energy ${ }^{a}$ & 14.13 & 14.39 & 14.40 & 14.37 & 14.48 & 14.51 & 14.38 & 14.35 \\
\hline Ratio CP:DE ${ }^{b}$ & 13.52 & 13.76 & 13.54 & 13.64 & 11.26 & 11.23 & 11.27 & 11.22 \\
\hline Chromium (ppb) & 415 & 678 & 772 & 1010 & 376 & 515 & 672 & 1000 \\
\hline
\end{tabular}

${ }^{a}$ Digestible energy (DE) calculated from the analysed nutrient content according to the formula: DE $\left(\mathrm{MJ} \cdot \mathrm{kg}^{-1} \mathrm{DM}\right)=18.974 *$ crude protein $\left(\mathrm{g} \cdot \mathrm{g}^{-1} \mathrm{DM}\right)+33.472 *$ crude fat $\left(\mathrm{g} \cdot \mathrm{g}^{-1} \mathrm{DM}\right)-21.216 *$ crude fibre $\left(\mathrm{g} \cdot \mathrm{g}^{-1} \mathrm{DM}\right)$ $+16.611^{*}$ nitrogen-free extracts $\left(\mathrm{g} \cdot \mathrm{g}^{-1} \mathrm{DM}\right)$.

${ }^{\mathrm{h}}$ Ratio crude protein:digestible energy.

Table III. Effect of chromium from chromium yeast on growth performance of growing- finishing pigsa.

\begin{tabular}{|c|c|c|c|c|c|}
\hline \multirow[b]{2}{*}{ Item } & \multicolumn{5}{|c|}{ Treatment $^{b}$} \\
\hline & $\mathrm{C}$ & $\mathrm{C} 200$ & $\mathrm{C} 400$ & $\mathrm{C} 800$ & SEM \\
\hline \multicolumn{6}{|l|}{ Daily gain (g) } \\
\hline Grower & 688 & 695 & 661 & 679 & 14.8 \\
\hline Finisherd & 783 & 855 & 807 & 786 & 21.5 \\
\hline Total triale & 741 & 785 & 742 & 736 & 15.8 \\
\hline \multicolumn{6}{|c|}{ Daily feed intake $(\mathrm{kg})$} \\
\hline Growerc & 1.55 & 1.53 & 1.53 & 1.54 & 0.012 \\
\hline Finisher & 2.40 & 2.43 & 2.41 & 2.43 & 0.023 \\
\hline Total trial & 2.03 & 2.04 & 2.02 & 2.03 & 0.013 \\
\hline \multicolumn{6}{|c|}{ Feed conversion ratio $\left(\mathrm{kg} \cdot \mathrm{kg}^{-1}\right)$} \\
\hline Grower & 2.26 & 2.19 & 2.31 & 2.27 & 0.051 \\
\hline Finisherc & 3.11 & 2.88 & 3.01 & 3.11 & 0.081 \\
\hline Total trial ${ }^{\mathrm{f}}$ & 2.78 & 2.61 & 2.73 & 2.75 & 0.058 \\
\hline
\end{tabular}

"Mean body weight at the initiation of the trial, at the initiation of the finisher phase, and at the trial termination was $24.5,57.4$ and $105.4 \mathrm{~kg}$, respectively.

${ }^{\mathrm{b}}$ Data are least-square means of $10 \mathrm{pigs}$, standard error of the mean $(\mathrm{SEM})=$ root $\mathrm{MSE} / \mathrm{N}$.

'Quadratic, $P<0.10$.

d Single degree of freedom contrast of treatment C vs. C200, $P<0.03$.

- Single degree of fireedom contrast of treatment $C$ vs. $C 200, P<0.06$.

isingle degree of freedom contrast of treatment $\mathrm{C}$ vs. $\mathrm{C} 200, P<0.05$. 


\subsection{Carcass measurements}

Compared to treatment $\mathrm{C}$, the dressing percentage of the $\mathrm{C} 200$ group was impaired $(P<0.09)$, but a higher dietary $\mathrm{Cr}$ supplementation had no further effects (table IV). In addition, there was a linear increase in palmitoleic acid in the carcass lipids $(P<0.04)$ (table V). Dietary $\mathrm{Cr}$ did not affect dissection parameters, chemical composition nor fatty acid profiles.

\subsection{Plasma metabolites and hormones}

Increasing amounts of added $\mathrm{Cr}$ reduced triglyceride concentrations $(P<0.03)$ linearly in plasma after $24 \mathrm{~h}$ of fasting (t0), whereas the NEFA concentrations increased linearly $(P<0.08)$ (table $V I)$. In addition, there was a numerical increase in urea $\mathrm{N}$ concentration at t0 with incremental amounts of dietary $\mathrm{Cr}$.
Two hours post-feeding ( $\mathrm{t} 2$ ), the $\mathrm{Cr}$ effect on BHB was quadratic $(P<0.04)$, with the $\mathrm{C} 400$ group showing the highest value. In addition, the change in the BHB concentration from to to $\mathrm{t} 2$ was linear $(P<0.09)$ and negative in pigs with treatment $\mathrm{C}\left(-11.4 \mathrm{mmol} \cdot \mathrm{L}^{-1}\right)$ and positive in pigs with treatment $\mathrm{C} 800\left(+7.2 \mathrm{mmol} \cdot \mathrm{L}^{-1}\right)$. Pigs with treatment $\mathrm{C} 200\left(-0.8 \mathrm{mmol} \cdot \mathrm{L}^{-1}\right)$ and $\mathrm{C} 400\left(+0.7 \mathrm{mmol} \cdot \mathrm{L}^{-1}\right)$ showed intermediate values. Plasma triglycerides of the $\mathrm{C} 200$ and C800 pigs were reduced at $\mathrm{t} 2$ compared with group $\mathrm{C}(P<0.06)$, but the triglyceride concentrations of the $\mathrm{C} 400$ pigs did not differ from treatment $C$. The added chromium did not significantly affect hormone concentrations but the insulin values and insulin to glucagon ratios, as well as the insulin to glucose ratios, seemed to be lower when $\mathrm{Cr}$ was supplemented (table VII).

Table IV. Effect of chromium from chromium yeast on carcass measurements and chemical composition of pig carcasses.

\begin{tabular}{lccccc}
\hline & \multicolumn{5}{c}{ Treatment $^{\mathrm{a}}$} \\
\cline { 2 - 6 } Item $^{\mathrm{b}}$ & $\mathrm{C}$ & $\mathrm{C} 200$ & $\mathrm{C} 400$ & $\mathrm{C} 800$ & SEM \\
\hline Dissection parameters (\% of carcass) & & & & & \\
$\quad$ Hot carcass weight (kg) & 83.0 & 83.7 & 83.9 & 83.1 & 0.58 \\
$\quad$ Dressing percentagec & 79.28 & 78.05 & 79.42 & 79.75 & 0.491 \\
Lean cuts & 54.59 & 55.08 & 54.16 & 53.58 & 0.738 \\
Fat cuts & 13.87 & 13.88 & 13.96 & 14.41 & 0.477 \\
Abdominal fat & 1.63 & 1.49 & 1.51 & 1.70 & 0.135 \\
Fat thickness (mm) & 17.9 & 18.8 & 17.7 & 18.6 & 0.48 \\
Chemical composition (\% of DM) & & & & & \\
Dry matter $(\%)$ & 41.30 & 41.21 & 40.89 & 41.39 & 0.820 \\
Ash & 7.55 & 7.54 & 7.64 & 7.22 & 0.233 \\
Protein & 41.69 & 41.51 & 42.15 & 39.29 & 1.459 \\
Fat & 49.67 & 50.28 & 49.49 & 52.48 & 1.528 \\
\hline
\end{tabular}

\footnotetext{
a Data are least square means of ten pigs, standard error of the mean (SEM) $=$ root MSE $/ \mathrm{Nn}$.

${ }^{h}$ Lean cuts: shoulder, back, and ham without fat layers; Fat cuts: fat layers above shoulder, back, and ham; Fat thickness: thinnest part in the middle of the back between two whirls.

c Single degree of freedom contrast of treatment C vs. C200, $P<0.09$.

${ }^{\lrcorner}$Hot carcass weight was used as a covariate.
} 
Table V. Effect of chromium from chromium yeast on the fatty acid profile of the extracted fat of pig carcasses $^{\mathrm{a}}$.

\begin{tabular}{lrrrrr}
\hline & \multicolumn{5}{c}{ Treatment $^{\mathrm{b}}$} \\
\cline { 2 - 6 } Item $^{\mathrm{c}}$ & \multicolumn{1}{c}{$\mathrm{C}$} & $\mathrm{C} 200$ & $\mathrm{C} 400$ & $\mathrm{C} 800$ & SEM \\
\hline SFA $18: 0$ & 41.89 & 41.64 & 41.17 & 41.26 & 0.499 \\
C 16:0 & 23.78 & 23.82 & 23.62 & 23.84 & 0.203 \\
C 18:0 & 15.88 & 15.61 & 15.35 & 15.15 & 0.357 \\
MUFA & 46.76 & 47.06 & 47.42 & 47.56 & 0.484 \\
C 16:1 & 2.45 & 2.53 & 2.53 & 2.68 & 0.070 \\
C 18:1 & 42.85 & 43.13 & 43.44 & 43.51 & 0.435 \\
PUFA & 11.36 & 11.30 & 11.42 & 11.18 & 0.142 \\
C 18:2 & 9.68 & 9.67 & 9.73 & 9.70 & 0.127 \\
C 18:3 & 0.75 & 0.76 & 0.75 & 0.73 & 0.017 \\
\hline
\end{tabular}

a In \% of the extracted fat of the carcass; fat content of the dry matter (DM) of the carcass was used as a covariate.

${ }^{b}$ Data are least-square means of ten pigs, standard error of the mean (SEM) $=$ root MSE $/ \mathrm{V}$.

' SFA: saturated fatty acids; MUFA: monounsaturated fatty acids; PUFA: polyunsaturated fatty acids.

${ }^{d}$ Linear, $P<0.04$.

\section{DISCUSSION}

\subsection{Diets}

The CP:DE ratios in the diets were slightly higher than the recommendations (12.6 to $11.3 \mathrm{~g} \mathrm{CP}[\mathrm{MJ}] \mathrm{DE}^{-1}$ for growing and 11.3 to $9.9 \mathrm{~g} \mathrm{CP}[\mathrm{MJ}] \mathrm{DE}^{-1}$ for finishing pigs) (table II) $[4,24]$. Thus, we can assume that the pigs were provided with adequate levels of protein. The chromium contents of the pelleted diets, analysed by means of atomic absorption spectrometry, were higher than expected. Besides the feedstuff $\mathrm{Cr}$ concentration, contamination with inorganic complexed $\mathrm{Cr}$ during feed processing (milling, mixing and pelleting) probably influenced the amount of total chromium [13]. Wenk et al. [30] reported an increased Cr content of $35 \%$ due to pelleting processes. The authors concluded that the increase did not affect the amount of bioavailable $\mathrm{Cr}$. The content of bioavailable $\mathrm{Cr}$ is, however, far lower than the total $\mathrm{Cr}$ content of the feedstuff [22].

\subsection{Growth performance}

$\mathrm{Cr}$ requirements depend on many individual and environmental factors and therefore, comparisons of the results from different $\mathrm{Cr}$ studies have to be used carefully. For example, Lindemann et al. [14] and Ward et al. [29] observed interactions between dietary $\mathrm{Cr}$ and dietary lysine levels. Boleman et al. [3] and Mooney and Cromwell [21] reported an influence of duration of $\mathrm{Cr}$ supply on $\mathrm{Cr}$ effects.

Daily feed intake was similar in all treatments since the slight $\mathrm{Cr}$ effect in the growing period could be ignored because differences between treatments were only 10 to $20 \mathrm{~g} \cdot \mathrm{d}^{-1}$. The effects on daily gain were inversely mirrored by the feed conversion ratios. We have no explanation to this phenomenon since it tended to follow a quadratic response. To our knowledge, no dose response study has reported such an effect on daily gain and feed conversion ratio. Mooney and Cromwell [21] reported higher daily gain when growing pigs 
Table VI. Effect of chromium from chromium yeast on plasma metabolites of pigs both after 24-h fasting and 2-h postprandial on experimental day $88(87.4 \mathrm{~kg} \mathrm{LW})$.

\begin{tabular}{lccccc}
\hline & \multicolumn{5}{c}{ Treatment $^{\mathrm{a}}$} \\
\cline { 2 - 6 } Item $^{\mathrm{b}}$ & $\mathrm{C}$ & $\mathrm{C} 200$ & $\mathrm{C} 400$ & $\mathrm{C} 800$ & SEM \\
\hline After 24-h fasting $(\mathrm{t} 0)$ & & & & \\
$\quad$ Total protein $\left(\mathrm{g} \cdot \mathrm{L}^{-1}\right)$ & 71.2 & 71.0 & 71.6 & 69.3 & 1.22 \\
Urea N $\left(\mathrm{mmol} \cdot \mathrm{L}^{-1}\right)$ & 3.27 & 3.50 & 3.51 & 3.74 & 0.215 \\
Triglycerides $\left(\mathrm{mmol} \cdot \mathrm{L}^{-1}\right)^{\mathrm{c}}$ & 0.571 & 0.554 & 0.490 & 0.480 & 0.0310 \\
NEFA $\left(\mathrm{mmol} \cdot \mathrm{L}^{-1}\right)^{\mathrm{d}}$ & 0.148 & 0.187 & 0.184 & 0.243 & 0.0359 \\
$\beta$-hydroxy-butyrate $\left(\mu \mathrm{mol} \cdot \mathrm{L}^{-1}\right)$ & 62.9 & 55.0 & 67.0 & 42.7 & 7.22 \\
Cholesterol $\left(\mathrm{mmol} \cdot \mathrm{L}^{-1}\right)$ & 2.81 & 2.91 & 2.61 & 2.80 & 0.099 \\
HDL-cholesterol $\left(\mathrm{mmol} \cdot \mathrm{L}^{-1}\right)$ & 1.22 & 1.30 & 1.15 & 1.23 & 0.048 \\
Glucose $\left(\mathrm{mmol} \cdot \mathrm{L}^{-1}\right)$ & 5.19 & 5.27 & 5.13 & 5.12 & 0.152 \\
2-h post-feeding $(\mathrm{t} 2)$ & & & & & \\
Total protein $\left(\mathrm{g} \cdot \mathrm{L}^{-1}\right)$ & 71.8 & 70.7 & 72.4 & 71.1 & 1.26 \\
Urea $\mathrm{N}\left(\mathrm{mmol} \cdot \mathrm{L}^{-1}\right)$ & 4.44 & 4.63 & 4.65 & 4.92 & 0.259 \\
Triglycerides $\left(\mathrm{mmol} \cdot \mathrm{L}^{-1}\right)$ & 0.522 & 0.422 & 0.483 & 0.421 & 0.0358 \\
NEFA $\left(\mathrm{mmol} \cdot \mathrm{L}^{-1}\right) \mathrm{e}$ & 0.038 & 0.036 & 0.050 & 0.040 & 0.0051 \\
$\beta$-hydroxy-butyrate $\left(\mu \mathrm{mol} \cdot \mathrm{L}^{-1}\right)^{\mathrm{fg}}$ & 51.5 & 55.8 & 66.3 & 49.9 & 5.31 \\
Cholesterol $\left(\mathrm{mmol} \cdot \mathrm{L}^{-1}\right)$ & 2.79 & 2.78 & 2.61 & 2.79 & 0.085 \\
HDL-cholesterol $\left(\mathrm{mmol} \cdot \mathrm{L}^{-1}\right)$ & 1.22 & 1.25 & 1.18 & 1.26 & 0.051 \\
Glucose $\left(\mathrm{mmol} \cdot \mathrm{L}^{-1}\right)$ & 5.35 & 5.28 & 5.23 & 5.07 & 0.184 \\
\hline
\end{tabular}

"Data are least-square means of ten pigs, standard error of the mean (SEM) $=$ root MSE $/ \sqrt{ }$.

${ }^{\mathrm{h}}$ NEFA: non-esterified fatty acids; HDL: high density lipoproteins.

c Linear, $P<0.03$.

d Linear, $P<0.08$.

' Single degree of freedom contrast of treatment C vs. C400, $P<0.10$.

${ }^{\mathrm{C}}$ Quadratic, $P<0.04$.

g Single degree of freedom contrast of treatment $\mathrm{C}$ vs. $\mathrm{C} 400, P<0.06$.

received $200 \mathrm{ppb} \mathrm{Cr}$ as $\mathrm{Cr}$ picolinate $(\mathrm{CrP})$ compared to pigs fed 0 or $400 \mathrm{ppb} \mathrm{Cr} P$ but they found in addition an increased daily feed intake which abolished the benefit of growth rate. Min et al. [19] observed lower daily feed intakes but no effect on daily gain in finishing pigs supplied $200 \mathrm{ppb} \mathrm{CrP}$ compared to those provided with 0,100 and $400 \mathrm{ppb}$. In contrast, Page et al. [25] reported a linear decline in both daily gain and feed intake with an increasing dietary $\mathrm{CrP}$ level $(0,100,200,400,800 \mathrm{ppb} \mathrm{Cr} P)$. Lindemann et al. [14] and Grela et al. [9] did not determine any dose-dependent response on performance due to Cr. Nevertheless, in the present study an improved daily gain of $5.9 \%$ and feed conversion ratio of $6.1 \%$ in treatment C200 compared to treatment C indicated that $200 \mathrm{ppb}$ dietary $\mathrm{Cr}$ provided the best effects under our experimental conditions, particularly in the finishing period. However, studies carried out with only one level of $\mathrm{Cr}$ supplementation (nearly all with $200 \mathrm{ppb} \mathrm{Cr}$ ) also demonstrated variable results in daily gain, feed intake and feed conversion rate which were also partly dependent on other nutritional and nonnutritional factors [3, 14, 20, 29]. It should be noted that with the exception of one study [3], the published data refer to ad libitum 
Table VII. Effect of chromium from chromium yeast on plasma hormones of pigs both after $24-\mathrm{h}$ fasting and 2-h postprandial on experimental day $88(87.4 \mathrm{~kg} \mathrm{LW})$.

\begin{tabular}{|c|c|c|c|c|c|}
\hline \multirow[b]{2}{*}{ Item $^{\text {b }}$} & \multicolumn{5}{|c|}{ Treatment $^{\mathrm{a}}$} \\
\hline & $\mathrm{C}$ & $\mathrm{C} 200$ & $\mathrm{C} 400$ & $\mathrm{C} 800$ & SEM \\
\hline \multicolumn{6}{|l|}{ After $24-h$ fasting (t0) } \\
\hline Insulin $\left(\mu \mathrm{U} \cdot \mathrm{mL}^{-1}\right)$ & 8.45 & 8.95 & 7.20 & 9.90 & 1.109 \\
\hline Glucagon (pg $\left.\cdot \mathrm{mL}^{-1}\right)$ & 76.3 & 90.5 & 72.1 & 92.6 & 4.71 \\
\hline Ratio insulin: glucagon & 5.11 & 5.01 & 4.64 & 4.98 & 0.819 \\
\hline Ratio insulin: glucose & 1.17 & 1.21 & 1.02 & 1.37 & 0.148 \\
\hline $\mathrm{T}_{3}\left(\mathrm{nmol} \cdot \mathrm{L}^{-1}\right)$ & 0.93 & 1.04 & 0.94 & 1.06 & 0.083 \\
\hline $\mathrm{T}_{4}\left(\mathrm{nmol} \cdot \mathrm{L}^{-1}\right)$ & 52.0 & 56.8 & 53.7 & 52.8 & 2.26 \\
\hline \multicolumn{6}{|l|}{ 2-h post-feeding $(\mathrm{t} 2)$} \\
\hline Insulin $\left(\mu \mathrm{U} \cdot \mathrm{mL}^{-1}\right)$ & 35.50 & 30.00 & 30.40 & 28.45 & 5.899 \\
\hline Glucagon $\left(\mathrm{pg} \cdot \mathrm{mL}^{-1}\right)$ & 115.9 & 123.4 & 103.2 & 128.0 & 7.33 \\
\hline Ratio insulin: glucagon & 16.62 & 11.10 & 13.17 & 10.22 & 2.81 \\
\hline Ratio insulin: glucose & 4.70 & 4.46 & 4.32 & 3.98 & 0.953 \\
\hline $\mathrm{T}_{3}\left(\mathrm{nmol} \cdot \mathrm{L}^{-1}\right)$ & 1.21 & 1.32 & 1.36 & 1.37 & 0.084 \\
\hline $\mathrm{T}_{4}\left(\mathrm{nmol} \cdot \mathrm{L}^{-1}\right)$ & 60.5 & 63.2 & 64.3 & 62.9 & 3.39 \\
\hline
\end{tabular}

a Data are least-square means of ten pigs, standard error of the mean (SEM) $=$ root MSE $/ \sqrt{ }$.

${ }^{\mathrm{b}}$ Ratio insulin: glucagon (pg $\cdot \mathrm{mL}^{-1}: \mathrm{pg} \cdot \mathrm{mL}^{-1}$ ), insulin $\mathrm{pg} \cdot \mathrm{mL}^{-1}=\mu \mathrm{U} \cdot \mathrm{mL}^{-1} * 45 \mathrm{pg} \cdot \mu \mathrm{U}^{-1}$; ratio insulin:glucose $\left(\left(\mathrm{mol} \cdot \mathrm{L}^{-1}: \mathrm{mol} \cdot \mathrm{L}^{-1}\right) * 10^{-8}\right)$, insulin $\mathrm{pmol} \cdot \mathrm{L}^{-1}=\mu \mathrm{U} \cdot \mathrm{mL}^{-1} * 7.175 \mathrm{pmol} \cdot \mu \mathrm{U}^{-1}$.

trials leading to $\mathrm{Cr}$ effects on feed intake which may have been prevented by the restricted feeding level applied in this present study. We assume that $\mathrm{Cr}$ effects on growth performance among other dietary factors such as lysine [14, 29] might also be affected by feeding regime.

\subsection{Carcass measurements}

Although pigs were slaughtered in a similar manner 7 days after they exceeded $97 \mathrm{~kg}$ live weight, differences in final body weight occurred. Since hot carcass weights were similar, the final weights were inversely mirrored by dressing percentages (table IV). The weights of the viscera (data not shown) did not differ and thus we suggest that different residual fillings of the gastrointestinal tract may have caused the differences in dressing percentages.
Although several experiments that were performed with varying levels of dietary $\mathrm{Cr}$ demonstrated a decrease in back fat thickness and fat accretion rate $[9,14,19,25]$ and increase in lean or muscle percentage $[14,25]$, no clear dose-response relationship could be established between $\mathrm{Cr}$ dosage and nutrient deposition, which is in good agreement with the present results. In contrast to previous studies, we observed elevated fat contents and proportion of fat cuts in treatment $\mathrm{C} 800$ compared to those of treatment $\mathrm{C}$, which implies an increasing rather than decreasing effect on fat (table IV). The weak effect on nutrient deposition could most likely be attributed to the lean pig breed used, and/or to the restricted feeding scale since it is well known that carcasses of pigs fed ad libitum compared to those of pigs fed on a restricted feeding scale usually have higher fat and reduced protein contents as well as lower percentages of 
lean cuts $[2,31]$. In addition, a proper protein to energy ratio in the diet probably also prevented excessive fat deposition. In most of the cited studies, back fat thickness of the control groups was higher than $25 \mathrm{~mm}$ compared to a mean of $18.3 \mathrm{~mm}$ in this study, suggesting that high fat deposition is a prerequisite for a fat-reducing effect of $\mathrm{Cr}$ supplementation.

In contrast to the present data which demonstrated no effect of $\mathrm{Cr}$ supplementation on fatty acid profiles except for palmitoleic acid (table V), Grela et al. [9] reported decreased contents of saturated fatty acids (SFA) and enhanced contents of polyunsaturated fatty acids (PUFA) in back fat due to $\mathrm{Cr}(0,200,500 \mathrm{ppb} \mathrm{Cr}$ as $\mathrm{Cr}$ yeast). This was, however, an indirect $\mathrm{Cr}$ effect because fat deposition on the back was also reduced by $\mathrm{Cr}$, and PUFA in the back fat of the control pigs were probably diluted by SFA deriving from de novo fatty acid synthesis $[2,31]$.

\subsection{Plasma metabolites and hormones}

Plasma profiles of metabolites and hormones of a single blood collection, as in the present study, merely reflect the physiological state of the animals at the time of bleeding and the results should therefore be interpreted carefully. Present plasma data may however give evidence of alterations due to dietary $\mathrm{Cr}$ (tables VI and VII).

Several studies with pigs have demonstrated the involvement of $\mathrm{Cr}$ in insulin metabolism [1, 7, 8, 10, 15]. Moreover, a recent investigation has demonstrated the probable mechanism in which $\mathrm{Cr}$ is involved in improving insulin action [6]. The slightly, but not significant, lower insulin concentrations in plasma of $\mathrm{Cr}$ treated pigs at $\mathrm{t} 2$ may be explained by the postulated hypothesis by McCarty [16] that an improved effectiveness of insulin by dietary $\mathrm{Cr}$ must result in a compensatory down-regulation of insulin secretion. On the other hand, glucagon secretion should increase due to $\mathrm{Cr}$ treat- ment [16]; however, the plasma glucagon levels at $\mathrm{t} 2$, and the insulin:glucagon ratios, indicating the net effect of both hormones [28], did not confirm this hypothesis since glucagon concentrations in plasma of pigs fed diet $\mathrm{C} 400$ were lower than those in pigs fed treatment $\mathrm{C}$. Plasma insulin and glucagon levels after $24 \mathrm{~h}$ of fasting also showed no relationship to $\mathrm{Cr}$ dosage.

However, the linear decline in plasma triglycerides as well as the linear increase in NEFA suggest an elevated catabolic state during fasting with incremental $\mathrm{Cr}$ supplementation [12]. The numerical but non-significant elevated plasma urea $\mathrm{N}$ concentrations with increasing $\mathrm{Cr}$ levels at $\mathrm{t} 0$ and $\mathrm{t} 2$ are consistent with this hypothesis. Moreover, the changes in plasma $\mathrm{BHB}$ level from to to $\mathrm{t} 2$, which as was normally expected [5] negative in pigs fed diet $\mathrm{C}$, but were unchanged in pigs fed diets $\mathrm{C} 200$ and $\mathrm{C} 400$, and positive in pigs of treatment $\mathrm{C} 800$ further support the hypothesis of an altered metabolism. Since ketogenesis is usually associated with gluconeogenesis [5], we assume an enhanced gluconeogenesis rate due to increasing Cr supplementation.

\section{CONCLUSION}

The present data suggest that supplementation with $200 \mathrm{ppb} \mathrm{Cr}$ fed as $\mathrm{Cr}$ yeast had a favourable impact on growth performance and feed conversion rate, but we have no explanation for the finding that supplementations of 400 and $800 \mathrm{ppb} \mathrm{Cr}$ did not affect performance. Carcass evaluation did not support the results of other studies which reported enhanced protein or decreased fat deposition by $\mathrm{Cr}$. On the contrary, our data implicate rather an elevated fat accretion due to $\mathrm{Cr}$ supplementation. We assume that a high fat deposition is a prerequisite for dietary $\mathrm{Cr}$ to lower fat accretion since pigs used in other studies had comparatively high fat depositions. Low effects on plasma hormones and metabolites suggest an altered physiology due to $\mathrm{Cr}$. 
While the direction of many observed responses were as hypothesised, the responses of $\mathrm{Cr}$ supplementation, especially on carcass characteristics and plasma traits, were rather weak and further research is needed to study the impact of $\mathrm{Cr}$ supplementation on the physiology and performances of the animals. Therefore, further experiments are planned to investigate possible interactions between $\mathrm{Cr}$ supplementation and other nutritional factors.

\section{REFERENCES}

[1] Amoikon E.K., Fernandez J.M., Southern L.L., Thompson D.L.Jr., Ward T.L., Olcott B.M., Effect of chromium tripicolinate on growth, glucose tolerance, insulin sensitivity, plasma metabolites, and growth hormone in pigs, J. Anim. Sci. 73 (1995) 1123-1130.

[2] Bee G., Der Nährstoffgehalt und das Fettsäuretypenmuster des Gesamtkörpers von Mastschweinen unter Berücksichtigung der Fütterung und der Wachstumsgeschwindigkeit, Dissertation ETH No. 10043, Zurich, Switzerland, 1993.

[3] Boleman S.L., Boleman S.J., Bidner T.D., Southern L.L., Ward T.L., Pontif J.E., Pike M.M., Effect of chromium picolinate on growth, body composition, and tissue accretion in pigs, J. Anim. Sci. 73 (1995) 2033-2042.

[4] Boltshauser M., Jost M., Kessler J., Stoll P., Fütterungsempfehlungen und Nährwerttabellen für Schweine, Landwirtschaftliche Lehrmittelzentrale, Zollikofen, Switzerland, 1993.

[5] Bruss M.L., Ketogenesis and Ketosis, in: Kaneko J.J. (Ed.), Clinical Biochemistry of Domestic Animals, San Diego, 1989, pp. 86-105.

[6] Davis C.M., Vincent J.B., Chromium in carbohydrate and lipid metabolism, JBIC 2 (1997) 675-679.

[7] Evans G.W., Bowman T.D., Chromium picolinate increases membrane fluidity and rate of insulin internalization, J. Inorg. Biochem. 46 (1992) 243-250.

[8] Evock-Clover C.M., Polansky M.M., Anderson R.A., Steele N.C., Dietary chromium supplementation with or without somatotropin treatment alters serum hormones and metabolites in growing pigs without affecting growth performance, J. Nutr. 123 (1993) 1504-1512.

[9] Grela E.R., Studzinski T., Rabos A., Winiarska A., Dziduch J., Effect of a chromium yeast supplement in growing-finishing pig diets on performance, carcass traits and fatty acid composition of adipose tissue, J. Anim. Feed Sci. 6 (1997) 87-100.

[10] Guan X.F., Snow J.L., Ku P., Burton J., Trottier N.L., Effect of dietary chromium supplementation on plasma glucosekinetics in barrows and gilts, J. Anim. Sci. 75 (Suppl. 1) (1997) 189 (Abstr.).

[11] Hara A., Radin N.S., Lipid extraction of tissues with a low-toxicity solvent, Anal. Biochem. 90 (1978) 420-426.

[12] Kaneko J.J., Carbohydrate metabolism and its diseases, in: Kaneko J.J. (Ed.), Clinical Biochemistry of Domestic Animals, San Diego, 1989, pp. 44-85.

[13] Kumpulainen J.T., Chromium content of foods and diets, Biol. Trace Elem. Res. 32 (1992) 9-18.

[14] Lindemann M.D., Wood C.M., Harper A.F., Kornegay E.T., Anderson R.A., Dietary chromium picolinate additions improve gain: feed and carcass characteristics in growing-finishing pigs and increase litter size in reproducing sows, J. Anim. Sci. 73 (1995) 457-465.

[15] Matthews J.O., Southern L.L., Fernandez J.M., Chapa A.M., Gentry L.R., Bidner T.D., Effects of dietary chromium tripicolinate or chromium propionate on growth, plasma metabolites, glucose tolerance, and insulin sensitivity in pigs, J. Anim. Sci. 75 (Suppl. 1) (1997) 187(Abstr.).

[16] McCarty M.F., Chromium and other insulin sensitizers may enhance glucagon secretion: implications for hypoglycemia and weight control, Med. Hypoth. 46 (1996) 77-80.

[17] Mertz W., Interaction of chromium with insulin: a progress report, Nutr. Rev. 56 (1998) 174-177.

[18] Metcalfe L.D., Smith J.F., The rapid preparation of fatty acid esters for gas chromatographic analyses, Anal. Chem. 33 (1961) 363-364.

[19] Min J.K., Kim W.Y., Chae B.J., Chung I.B., Shin I.S., Choi Y.J., Han I.K., Effects of chromium picolinate ( $\mathrm{CrP}$ ) on growth performance, carcass characteristics and serum traits in growing-finishing pigs, Asian J. Anim. Sci. 10 (1997) 8-14.

[20] Mooney K.W., Cromwell G.L., Effects of dietary chromium picolinate supplementation on growth, carcass characteristics, and accretion rates of carcass tissues in growing-finishing swine, J. Anim. Sci. 73 (1995) 3351-3357.

[21] Mooney K.W., Cromwell G.L., Efficacy of chromium picolinate and chromium chloride as potential carcass modifiers in swine, J. Anim. Sci. 75 (1997) 2661-2671

[22] Mordenti A., Piva G., Chromium in animal nutrition and possible effects on human health, in: Canali S., Tittarelli F., Sequi P. (Eds.), Chromium Environmental Issues, Milan, 1997, pp. 131-151. 
[23] Naumann C., Bassler R., Seibold R., Barth C., Methodenbuch Band III, VDLUFA, Darmstadt, 1997.

[24] NRC, Nutrient Requirements of Swine, 10th edn., National Academy Press, Washington, D.C., 1998.

[25] Page T.G., Southern L.L., Ward T.L., Thompson D.L., Effect of chromium picolinate on growth and serum and carcass traits of growing-finishing pigs, J. Anim. Sci. 71 (1993) 656-662.

[26] Rebsamen A., Schwörer D., Lorenz D., Die Schlachtkörperzerlegung beim Schwein in der MLP Sempach, Der Kleinviehzüchter 43 (1995) 223-259.

[27] SAS, SAS Users Guide: Statistics, Version 6.12 edn., SAS Institute Inc., Cary, NC, USA, 1998.
[28] Seitz H.J., Tarnowski W., Nahrungsabhängige Regulation des Intermediärstoffwechsels, in: Cremer H.-D., Hötzel D., Kühnau J. (Eds.), Biochemie und Physiologie der Ernährung, Stuttgart, 1980, pp. 399-452.

[29] Ward T.L., Southern L.L., Bidner T.D., Interactive effects of dietary chromium tripicolinate and crude protein level in growing-finishing pigs provided inadequate and adequate pen space, J. Anim. Sci. 75 (1997) 1001-1008.

[30] Wenk C., Gebert S., Pfirter H.P., Chromium supplements in the feed of growing pigs: influence on growth and meat quality, Arch. Anim. Nutr. 48 (1995) 71-81.

[31] Wood J.D., Fat deposition and the quality of fat tissue in meat animals, in: Wiseman J. (Ed.), Fats in Animal Nutrition, London, 1984. pp. $407-435$. 